\title{
Liquid Egg as an Alternative Protein Source in Calf Milk Replacers
}

\author{
K. J. Touchette, M. L. O'Brien, and J. A. Coalson \\ Merrick Animal Nutrition, Inc. \\ Union Center, WI 53962
}

\section{ABSTRACT}

The use of alternative proteins in milk replacer has been evaluated for their ability to decrease the cost of milk replacers without negatively impacting performance of the calf. Three studies were conducted to evaluate the performance of calves fed milk replacer utilizing liquid egg as an alternative protein and to determine the optimal concentration of liquid egg to include in milk replacers. Calves in trials 1 and 2 were assigned to a control diet of all milk protein replacer (MILK) or a diet formulated to contain 5\% of the diet $(13.5 \%$ of the protein) from liquid egg (5\%EGG). Calves in trial 3 were assigned to one of four diets: the control (MILK) and 5\% EGG diets fed in trials 1 and 2, or diets formulated to contain either 10 or $15 \%$ of the diet (27 or $40.5 \%$ of the protein) from liquid egg (10\%EGG, 15\%EGG). For all experiments, milk replacers were formulated to contain $20 \%$ protein, $20 \%$ fat and were fed at $454 \mathrm{~g} / \mathrm{d}$ reconstituted to $12 \% \mathrm{DM}$. Production of the diets containing egg protein utilized breaker eggs that were pasteurized during manufacturing. Holstein bull calves (n $=44$ for experiment $1, \mathrm{n}=38$ for experiment 2 , and $\mathrm{n}$ $=120$ for experiment 3 ), were purchased from an area sale barn. Calves were housed in individual hutches with water available free choice starting on $\mathrm{d} 0$. A commercially available calf starter was offered free choice beginning on $\mathrm{d} 7$ for experiments 1 and 2 and on $\mathrm{d} 1$ for experiment 3. Feed intake, scour scores, and antibiotic treatments were recorded daily. For experiment 1, calves fed 5\%EGG had greater weight gains than calves fed MILK. No differences in average daily feed intake were observed. For experiment 2, weight gains tended to be lower with 5\%EGG, whereas feed intakes and gain to feed ratios were similar between calves fed MILK or $5 \%$ EGG. For experiment 3, as the amount of egg in the diet increased, weight gain decreased in a linear fashion during the milk replacer feeding period, but the decrease in gain was significant only with the $15 \% \mathrm{EGG}$ diet. These results indicate that egg is an effective alter-

Received May 30, 2002.

Accepted February 14, 2003.

Corresponding author: K. J. Touchette; e-mail: ktouchette@ merricks.com. native protein source to milk protein in calf milk replacers when fed at levels up to $10 \%$ of the diet in a conventional feeding program of $0.45 \mathrm{~kg}$ per head per day.

(Key words: calf, alternative protein, liquid egg)

Abbreviation key: ADG = average daily gain, ADFI = average daily feed intake, MILK = all milk protein replacer, SDWE = spray dried whole egg, $\mathbf{W P C}=$ whey protein concentrate, 5\%EGG, 10\%EGG, 15\%EGG = a milk replacer formulated to contain 5,10 , and $15 \%$, respectively, of the diet from liquid egg.

\section{INTRODUCTION}

Historically, the "standard" milk replacer in the dairy industry has contained only all milk protein. Sources of milk protein utilized include whey, whey protein concentrate (WPC), skim milk, and casein. During the past $13 \mathrm{yr}$, prices of whey have fluctuated from a low of $\$ 0.31 / \mathrm{kg}$ of solids (1990) to a high of $\$ 0.62 / \mathrm{kg}$ of solids in 2001 (USDA, 2003). Prices for WPC have followed similar trends with a low cost of $\$ 1.01 / \mathrm{kg}$ of solids (1999) to a high of $\$ 1.72 / \mathrm{kg}$ of solids in 2001 (USDA, 2003). Due to large price fluctuations for ingredients and higher prices for all milk protein sources, alternative proteins have been evaluated extensively for use in calf milk replacers.

In addition to being an economically priced protein source, eggs possess many characteristics of a high quality animal feed ingredient. Typical nutrient analyses of liquid eggs received at Merrick Animal Nutrition, Inc., are $54 \%$ protein, $37 \%$ fat, and $4.2 \%$ ash. In addition, eggs can be utilized as a source of iron, phosphorus, trace minerals, and vitamins.

During the past $3 \mathrm{yr}$, the use of egg proteins as an alternative protein has been studied extensively. Previous researchers concluded that the use of spray dried whole egg (SDWE) as an alternative protein source resulted in reduced growth in young calves compared with calves fed an all milk protein replacer (Scott, et al., 1999; Kellogg et al., 2000; Quigley, 2002;). The experimental diets fed by Quigley (2002) and Scott et al. (1999) included 10 to $20 \%$ of the diet (25 to $50 \%$ of the protein) from SDWE. Quigley (2002) and Scott et al. (1999) did not feed calf starter prior to d 29 of their 


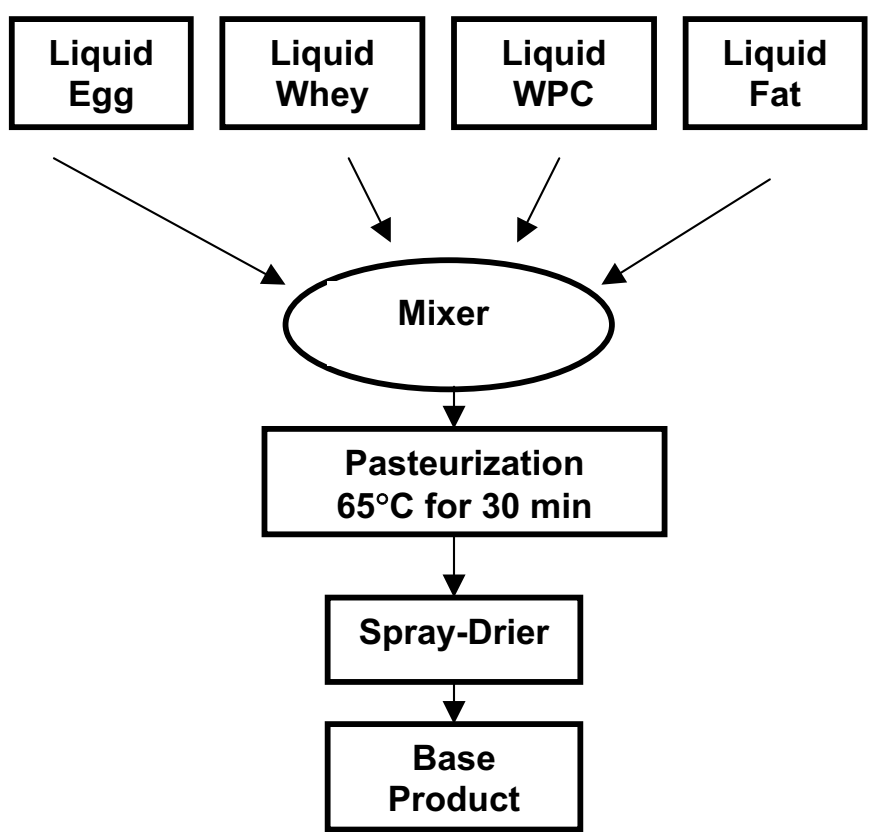

Figure 1. Manufacturing process of trial diets.

studies. The experimental diet fed in the study by Kellogg et al. (2000) contained SDWE at an inclusion rate (30\% of the diet or $56 \%$ of the protein) higher than those tested by Quigley (2002) and Scott et al. (1999).

Conversely, Hill and others (2001) found that feeding SDWE in calf milk replacer diets at lower inclusion rates $(3.7$ and $7.4 \%$ of the diet or 10 and $20 \%$ of the protein, respectively) did not reduce performance measurements compared with feeding an all milk protein replacer. Additionally, these researchers reported that the source of SDWE was important to calf performance.

Our objectives were to determine whether liquid egg can be used as an acceptable alternative protein source in calf milk replacer and to determine the optimal level of egg inclusion for acceptable calf performance when calves are fed a conventional feeding program of $454 \mathrm{~g} /$ $\mathrm{d}$ of milk replacer.

\section{MATERIALS AND METHODS}

\section{Manufacturing of Experimental Feeds}

All experimental feeds were manufactured at Merrick Animal Nutrition, Inc., Union Center, WI. The all milk protein replacers and milk replacers with egg protein were manufactured using liquid milk ingredients and liquid egg protein products. All basic ingredients (protein and fat sources) were blended in liquid form and then pasteurized at $65^{\circ} \mathrm{C}$ for 30 min before spray drying into the base product (Figure 1). The base was instantized and mixed with vitamins and minerals to complete the finished product. Nutrient compositions of final diets are found in Table 1. Analyses of final milk replacer diets were completed using approved Association of Analytical Chemists (AOAC) methods.

\section{General Trial Protocols}

Holstein bull calves were purchased from an area sale barn and transported to Merrick Animal Nutrition, Inc. Calf Research Farm. On arrival, calves were placed in fiberglass hutches, weighed, and assigned to a trial diet. For experiment 2 and 3, calves were assigned to a treatment and hutch depending on the initial weight of each animal. Jugular blood samples were collected and centrifuged for testing serum protein levels by refractometer for experiments 1 and 2 and for testing serum immunoglobulin G levels by Palm Lab (PalmLab, Inc. Newburg, WI) for experiment 3.

Trial diets were fed on arrival for calves in experiment 1 . For experiments 2 and 3, all calves were fed $227 \mathrm{~g}$ of a standard all milk diet (Gold Star, Merrick's Animal Nutrition, Union Center, WI) reconstituted to $12 \% \mathrm{DM}$, and trial diets began the following day. Experimental milk replacer diets were fed at $454 \mathrm{~g} / \mathrm{d}$ reconstituted to $12 \% \mathrm{DM}$ with refusals recorded daily. Calves were fed milk replacer in nipple bottles at approximately 0600 and $1700 \mathrm{~h}$ daily.

A texturized commercial calf starter (Domain, Inc. New Richmond, WI) was offered free choice beginning on $\mathrm{d} 7$ for experiments 1 and 2 and on $\mathrm{d} 1$ for experiment 3 . Feed refusals were recorded daily. Weaning occurred on d 43 dependent on each calf consuming at least 454 $\mathrm{g} / \mathrm{d}$ of calf starter for three consecutive days. Any calf not consuming sufficient calf starter to be weaned was offered one-half of the usual daily milk replacer feeding per day to encourage starter intake. Water was offered ad libitum beginning on $\mathrm{d} 0$.

Calves were weighed weekly. When calves required antibiotic treatments they were administered according to trial protocols and recorded daily. Antibiotic treatment was required for calves with severe scours, elevated temperature, respiratory infections, and infected navel or joints. Protocols for antibiotic treatments in experiment 1 were more aggressive than for experiments 2 and 3 . During experiment 1 , calves were treated more aggressively for a scour incidence (scour score of 3 or 4) and for high temperatures (greater than $38.9^{\circ} \mathrm{C}$ in experiment 1 compared with greater than $39.4^{\circ} \mathrm{C}$ in experiments 2 and 3 ).

Subjective fecal scores were recorded daily using a scale of 1 to 4 , where 1 = very firm, 2 = normal fecal consistency, 3 = watery, and $4=$ extremely watery. A scour day was defined as any day a fecal score of 3 or 4 was recorded. Any calf exhibiting signs of scours was 
TOUCHETTE ET AL.

Table 1. Nutrient composition of milk replacers and calf starters.

\begin{tabular}{|c|c|c|c|c|c|}
\hline & \multicolumn{4}{|c|}{$\%$ Egg in milk replacer diet } & \multirow[b]{2}{*}{ Starter } \\
\hline & $0 \%$ & $5 \%$ & $10 \%$ & $15 \%$ & \\
\hline \multicolumn{6}{|l|}{ Experiment 1} \\
\hline $\mathrm{CP}, \%$ & $19.55^{\mathrm{a}}$ & $19.01^{\mathrm{a}}$ & $\ldots$ & $\ldots$ & $18.00^{\mathrm{b}}$ \\
\hline CP from milk, \% & 19.55 & 16.41 & & & \\
\hline CP from egg, \% & 0.00 & 2.60 & & & \\
\hline Fat, $\%$ & $20.34^{\mathrm{a}}$ & $20.52^{\mathrm{a}}$ & $\ldots$ & $\ldots$ & $3.00^{\mathrm{b}}$ \\
\hline Crude fiber, \% & $0.30^{\mathrm{a}}$ & $0.39^{\mathrm{a}}$ & $\ldots$ & $\ldots$ & $7.00^{\mathrm{b}}$ \\
\hline $\mathrm{ADF}, \%$ & & & $\ldots$ & $\ldots$ & $9.00^{\mathrm{b}}$ \\
\hline Vitamin A, IU/kg, min & $15890^{\mathrm{b}}$ & $15890^{\mathrm{b}}$ & $\ldots$ & $\ldots$ & $33,333^{\mathrm{b}}$ \\
\hline Vitamin D-3, IU/kg, min & $3405^{\mathrm{b}}$ & $3405^{\mathrm{b}}$ & $\ldots$ & $\ldots$ & $6,666^{\mathrm{b}}$ \\
\hline Vitamin E, IU/kg, min & $68^{\mathrm{b}}$ & $68^{\mathrm{b}}$ & $\ldots$ & $\ldots$ & $111^{\mathrm{b}}$ \\
\hline Oxytetracycline, $\mathrm{mg} / \mathrm{kg}$ & $\ldots$ & $\ldots$ & $\ldots$ & $\ldots$ & $\ldots$ \\
\hline Neomycin, mg/kg & $\ldots$ & $\ldots$ & $\ldots$ & $\ldots$ & $\ldots$ \\
\hline Decoquinate, $\mathrm{mg} / \mathrm{kg}$ & $\ldots$ & $\ldots$ & $\ldots$ & $\ldots$ & $50.00^{\mathrm{b}}$ \\
\hline \multicolumn{6}{|l|}{ Experiment 2} \\
\hline $\mathrm{CP}, \%$ & $20.33^{\mathrm{a}}$ & $20.58^{\mathrm{a}}$ & $\ldots$ & $\ldots$ & $18.00^{\mathrm{b}}$ \\
\hline CP from milk, \% & 20.33 & 17.50 & & & \\
\hline CP from egg, \% & 0.00 & 3.08 & & & \\
\hline Fat, $\%$ & $20.65^{\mathrm{a}}$ & $20.86^{\mathrm{a}}$ & $\ldots$ & $\ldots$ & $5.00^{\mathrm{b}}$ \\
\hline Crude fiber, $\%$ & $0.04^{\mathrm{a}}$ & $0.06^{\mathrm{a}}$ & $\ldots$ & $\ldots$ & $7.00^{\mathrm{b}}$ \\
\hline $\mathrm{ADF}, \%$ & & & $\ldots$ & $\ldots$ & $9.00^{\mathrm{b}}$ \\
\hline Vitamin A, IU/kg, min & $15890^{\mathrm{b}}$ & $15890^{\mathrm{b}}$ & $\ldots$ & $\ldots$ & $33,333^{\mathrm{b}}$ \\
\hline Vitamin $\mathrm{D}-3, \mathrm{IU} / \mathrm{kg}$, min & $3405^{\mathrm{b}}$ & $3405^{\mathrm{b}}$ & $\ldots$ & $\ldots$ & $6,666^{b}$ \\
\hline Vitamin E, IU/kg, min & $68^{\mathrm{b}}$ & $68^{\mathrm{b}}$ & $\ldots$ & $\ldots$ & $111^{\mathrm{b}}$ \\
\hline Oxytetracycline, $\mathrm{mg} / \mathrm{kg}$ & $222.00^{\mathrm{b}}$ & $222.00^{\mathrm{b}}$ & $\ldots$ & $\ldots$ & \\
\hline Neomycin, mg/kg & $444.00^{\mathrm{b}}$ & $444.00^{\mathrm{b}}$ & $\ldots$ & $\ldots$ & \\
\hline Decoquinate, $\mathrm{mg} / \mathrm{kg}$ & $\ldots$ & $\ldots$ & $\ldots$ & $\ldots$ & $50.00^{\mathrm{b}}$ \\
\hline \multicolumn{6}{|l|}{ Experiment 3} \\
\hline $\mathrm{CP}, \%$ & $20.11^{\mathrm{a}}$ & $20.42^{\mathrm{a}}$ & $21.12^{\mathrm{a}}$ & $21.31^{\mathrm{a}}$ & $18.00^{\mathrm{b}}$ \\
\hline CP from milk, \% & 20.11 & 17.72 & 15.92 & 13.05 & \\
\hline CP from egg, $\%$ & 0.00 & 2.70 & 5.20 & 8.26 & \\
\hline Fat, $\%$ & $20.44^{\mathrm{a}}$ & $19.07^{\mathrm{a}}$ & $20.67^{\mathrm{a}}$ & $19.91^{\mathrm{a}}$ & $5.00^{\mathrm{b}}$ \\
\hline Crude fiber, $\%$ & $0.04^{\mathrm{a}}$ & $0.07^{\mathrm{a}}$ & $0.10^{\mathrm{a}}$ & $0.05^{\mathrm{a}}$ & $7.00^{\mathrm{b}}$ \\
\hline $\mathrm{ADF}, \%$ & & & & & $9.00^{\mathrm{b}}$ \\
\hline Vitamin A, IU/kg, min & $15890^{\mathrm{b}}$ & $15890^{\mathrm{b}}$ & $15890^{\mathrm{b}}$ & $15890^{\mathrm{b}}$ & $33,333^{\mathrm{b}}$ \\
\hline Vitamin $\mathrm{D}-3, \mathrm{IU} / \mathrm{kg}$, min & $3405^{\mathrm{b}}$ & $3405^{\mathrm{b}}$ & $3405^{\mathrm{b}}$ & $3405^{b}$ & $6,666^{b}$ \\
\hline Vitamin E, IU/kg, min & $68^{\mathrm{b}}$ & $68^{\mathrm{b}}$ & $68^{\mathrm{b}}$ & $68^{\mathrm{b}}$ & $111^{\mathrm{b}}$ \\
\hline Oxytetracycline, $\mathrm{mg} / \mathrm{kg}$ & $222.00^{\mathrm{b}}$ & $222.00^{\mathrm{b}}$ & $222.00^{\mathrm{b}}$ & $222.00^{\mathrm{b}}$ & $\ldots$ \\
\hline Neomycin, $\mathrm{mg} / \mathrm{kg}$ & $444.00^{\mathrm{b}}$ & $444.00^{\mathrm{b}}$ & $444.00^{\mathrm{b}}$ & $444.00^{\mathrm{b}}$ & $\ldots$ \\
\hline Decoquinate, $\mathrm{mg} / \mathrm{kg}$ & $\ldots$ & $\ldots$ & $\ldots$ & $\ldots$ & $50.00^{\mathrm{b}}$ \\
\hline
\end{tabular}

treated twice daily with oral rehydration therapy using a commercial electrolyte solution (Blue Ribbon Calf Electrolytes, Merrick's Animal Nutrition, Union Center, WI). Oral rehydration therapy continued until $1 \mathrm{~d}$ after signs of scours abated. Milk replacer feedings were unchanged during administration of electrolyte therapy.

\section{Experiment 1}

On arrival, calves $(\mathrm{n}=44)$ were randomly assigned to receive one of two diets: an all milk protein replacer (MILK) or a milk replacer formulated to contain 5\% of the diet (13.5\% of the protein) from liquid egg (5\%EGG). Milk replacer diets were not medicated.

\section{Experiment 2}

On arrival, calves $(n=38)$ were assigned to receive diets formulated to contain 0 or $5 \%$ of the diet $(0$ or $13.5 \%$ of the protein) from liquid egg (MILK, 5\%EGG, respectively). Milk replacer diets were medicated with Neo-Oxy 100/50 MR (Penn Field Animal Health, Omaha, NE). Calves were assigned to a milk replacer treatment as part of a randomized complete block design, using the initial weight of the calves as the blocking factor.

\section{Experiment 3}

On arrival, calves $(n=120)$ were assigned to receive one of four diets that were formulated to contain 0,5 , 
Table 2. Effect of level of egg on calf performance for experiment 1.

\begin{tabular}{lcccc}
\hline & \multicolumn{2}{c}{$\%$ Egg in the diet } & & \\
\cline { 2 - 3 } & $0 \%$ & $5 \%$ & SE & $P$-Value \\
\hline $\mathrm{n}$ & 20 & 22 & & \\
Total serum protein, mg/ml & 5.33 & 5.18 & 0.17 & 0.52 \\
BW, kg & & & & \\
d 0 & 44.51 & 46.70 & 0.75 & 0.04 \\
d 42 & 55.65 & 57.65 & 0.62 & 0.03 \\
d 56 & 64.13 & 66.47 & 0.66 & 0.02 \\
Total weight gain & 18.52 & 20.89 & 0.76 & 0.02 \\
ADG, kg/d & & & & \\
d 0-42 & 0.249 & 0.270 & 0.02 & 0.03 \\
d 0-56 & 0.324 & 0.366 & 0.01 & 0.03 \\
Total starter intake, kg & 49.30 & 54.80 & 4.78 & 0.35 \\
Gain:feed & 0.295 & 0.308 & 0.02 & 0.60 \\
Calves scouring, \% & 100.00 & 100.00 & & 0.76 \\
Calves treated, \% & 75.00 & 95.45 & & 0.06 \\
\hline
\end{tabular}

10 , or $15 \%$ of the $\operatorname{diet}(0,13.5,27$, or $40.5 \%$ of the protein) from liquid egg (MILK, 5\%EGG, 10\%EGG, 15\%EGG, respectively). Milk replacer diets were medicated with Neo-Oxy 100/50 MR (Penn Field Animal Health, Omaha, NE). Calves were assigned to a milk replacer treatment as part of a randomized complete block design, using the initial weight of the calves as the blocking factor.

\section{Statistical Analysis}

Weights, fecal scores, and daily calf starter intakes were summarized by week. These data were then analyzed using the general linear model procedure of Systat (1998). Means were separated using Fisher's least square difference and data were contrasted between treatments. For experiment 3 , linear and quadratic contrasts for the effect of increasing egg protein were used to evaluate the effects of treatment. Data for percent calves weaned at d 43, percent calves scoured, and percent calves treated, were analyzed using Pearson's chi square (Systat Version 8.0, 1998). Significance was declared at $P<0.05$ with trends reported at $P<0.10$. For experiment 1 , initial BW were used as a covariant to adjust the final weight and ADG values for analysis.

\section{RESULTS}

\section{Experiment 1}

Results of experiment 1 are shown in Table 2. Calf weights on arrival were used as a covariant for weekly weight analysis and adjusted least square means are reported. Beginning on d 14, calves fed the 5\%EGG diet had greater $(P<0.05)$ weekly weights. This difference was evident through the remainder of the trial. Total weight gains and $\mathrm{ADG}$ were also greater $(P<0.05)$ for calves fed the 5\%EGG diet than those fed the MILK
Table 3. Effect of level of egg on calf performance for experiment 2.

\begin{tabular}{lcccc}
\hline & \multicolumn{2}{c}{$\%$ Egg in the diet } & & \\
\cline { 2 - 3 } & $0 \%$ & $5 \%$ & SE & $P$-Value \\
\hline $\mathrm{n}$ & 17 & 17 & & \\
Total serum protein, mg/ml & 4.62 & 4.68 & 0.18 & 0.96 \\
BW, kg & & & & \\
d 0 & 43.19 & 44.00 & 1.02 & 0.58 \\
d 42 & 58.71 & 56.15 & 1.86 & 0.34 \\
d 56 & 70.24 & 72.73 & 2.93 & 0.55 \\
Total weight gain & 27.23 & 28.69 & 2.58 & 0.70 \\
ADG, kg/d & & & & \\
d 0 to 42 & 0.367 & 0.282 & 0.03 & 0.06 \\
d 0 to 56 & 0.486 & 0.513 & 0.05 & 0.70 \\
Total starter intake, kg & 46.80 & 49.13 & 4.62 & 0.74 \\
Gain:feed & 0.419 & 0.459 & 0.03 & 0.33 \\
Weaned at d 43, \% & 82.35 & 100.00 & & 0.07 \\
Calves scouring, \% & 70.59 & 64.70 & & 0.71 \\
Calves treated, \% & 52.94 & 64.70 & & 0.49 \\
\hline
\end{tabular}

diet. No differences in average weekly starter intakes, total starter intake, or gain:feed ratios were observed.

Overall health of the calves was excellent (mortality $=$ $4.5 \%$ ) with no differences between treatments for serum protein levels or percent calves scouring. Calves receiving the 5\%EGG diet exhibited a trend $(P=0.06)$ towards a greater percent of calves requiring antibiotic treatments.

\section{Experiment 2}

Results of experiment 2 are shown in Table 3. Calves fed both the MILK and 5\%EGG diet exhibited similar weekly weight gains, total weight gains, and gain:feed, with no significant differences reported. Calves fed the $5 \%$ EGG diet exhibited a trend $(P=0.06)$ toward lower ADG during $\mathrm{d} 1$ to 42 . However, by the end of the $56 \mathrm{~d}$ trial, this trend was no longer evident. Average weekly starter intakes and total starter intakes were not significantly different.

Mortality of calves (mortality $=10.5 \%$ ) was not different between calves receiving the MILK and 5\%EGG diets. There were also no differences between percentage of calves scouring or percentage of calves treated with antibiotics. Fewer calves were weaned at d 43 when fed the MILK diet compared with the 5\%EGG $\operatorname{diet}(P=0.07)$.

\section{Experiment 3}

As the level of egg in the diet increased, there was a linear decrease $(P<0.05)$ in ADG from d 1 to 42 , BW on $\mathrm{d} 42$, and gain:feed ratio (Table 4). However, for the entire 56-d trial the trend was for quadratic effects $(P$ $=0.09$ ) for $\mathrm{ADG}$, total weight gain and $\mathrm{BW}$ on $\mathrm{d} 56$ and total starter intake. As the amount of egg in the diet 
TOUCHETTE ET AL.

Table 4. Effect of level of egg on calf performance for Experiment 3.

\begin{tabular}{|c|c|c|c|c|c|c|c|}
\hline & \multicolumn{4}{|c|}{$\%$ Egg in diet } & \multirow[b]{2}{*}{$\mathrm{SE}$} & \multicolumn{2}{|c|}{ Contrasts } \\
\hline & $0 \%$ & $5 \%$ & $10 \%$ & $15 \%$ & & Linear & Quadratic \\
\hline $\mathrm{n}$ & 28 & 28 & 30 & 29 & & & \\
\hline $\begin{array}{l}\text { Serum IgG, mg/dl } \\
\text { BW, kg }\end{array}$ & 10.71 & 9.02 & 8.59 & 9.78 & 0.95 & 0.45 & 0.13 \\
\hline d 0 & 43.48 & 43.81 & 43.46 & 43.68 & 0.18 & 0.94 & 0.94 \\
\hline d $42^{1}$ & $64.30^{\mathrm{a}}$ & $63.69^{\mathrm{a}}$ & $63.68^{\mathrm{a}}$ & $58.66^{\mathrm{b}}$ & 1.56 & 0.03 & 0.15 \\
\hline $\mathrm{d} 56^{1}$ & $78.37^{\mathrm{ab}}$ & $79.22^{\mathrm{a}}$ & $79.96^{\mathrm{a}}$ & $72.96^{\mathrm{b}}$ & 2.05 & 0.10 & 0.09 \\
\hline Total weight gain, $\mathrm{kg}^{1}$ & $34.80^{\mathrm{ab}}$ & $35.34^{\mathrm{a}}$ & $35.48^{\mathrm{a}}$ & $29.23^{\mathrm{b}}$ & 2.06 & 0.07 & 0.09 \\
\hline $\mathrm{ADG}, \mathrm{kg} / \mathrm{d}$ & & & & & & & \\
\hline d $0-42^{1}$ & $0.494^{\mathrm{a}}$ & $0.472^{\mathrm{a}}$ & $0.481^{\mathrm{a}}$ & $0.356^{\mathrm{b}}$ & 0.04 & 0.01 & 0.15 \\
\hline d $0-56^{1}$ & $0.621^{\mathrm{ab}}$ & $0.631^{\mathrm{a}}$ & $0.634^{\mathrm{a}}$ & $0.522^{\mathrm{b}}$ & 0.04 & 0.07 & 0.09 \\
\hline Total starter intake, $\mathrm{kg}^{1}$ & $56.41^{\mathrm{ab}}$ & $58.77^{\mathrm{ab}}$ & $61.99^{\mathrm{a}}$ & $52.53^{\mathrm{b}}$ & 3.49 & 0.58 & 0.08 \\
\hline Gain:feed ${ }^{1}$ & $0.492^{\mathrm{a}}$ & $0.489^{\mathrm{a}}$ & $0.468^{\mathrm{a}}$ & $0.427^{\mathrm{b}}$ & 0.02 & 0.01 & 0.23 \\
\hline Weaned at $\mathrm{d} 43^{2}, \%$ & 96.43 & 100.00 & 100.00 & 89.66 & & & \\
\hline Calves scoured ${ }^{2}, \%$ & 34.48 & 14.81 & 13.79 & 20.69 & & & \\
\hline Calves treated $^{3}, \%$ & $55.17^{\mathrm{ab}}$ & $25.92^{\mathrm{a}}$ & $20.69^{\mathrm{a}}$ & $58.62^{b}$ & & & \\
\hline
\end{tabular}

\footnotetext{
${ }^{1}$ Values with no common superscripts differ by least square means analysis $(P<0.05)$.

${ }^{2}$ No treatment difference by Pearson's chi square analysis.

${ }^{3}$ Values with no common supercripts differ by Pearson's chi square analysis $(P<0.05)$.
}

fed increased, up to $10 \%$ of the diet (27\% of the protein) growth performance of the calves was similar. However, for the diet containing $15 \%$ egg ( $40.5 \%$ of the protein) these performance measures were greatly reduced.

As in the previous studies, overall health of the calves was excellent, with only $4.2 \%$ mortality for the entire study, and no differences between groups. No differences in serum IgG level or percent of calves scouring existed. However, calves receiving the 15\%EGG diet had a significantly greater percentage of calves treated than calves fed the 5\%EGG and 10\%EGG diets.

\section{DISCUSSION}

Results from experiment 3 demonstrated that high inclusion levels of liquid egg (greater than $10 \%$ of the formula, or $27 \%$ of the protein) may have detrimental effects on calf growth when compared to an all milk protein replacer. Earlier studies (Scott et al., 1999; Kellogg et al., 2000; Hill et al., 2001; Quigley, 2002) reported similar reduced growth rates at high inclusion rates of SDWE in milk replacer formulations.

When egg was included at levels up to $10 \%$ of the diet (27\% of the protein), as seen in the current study (experiment 3), growth performance of the calves was similar. These results are similar to those reported by Hill et al. (2001) who reported no detrimental effects on growth when SDWE was included at 3.7 and $7.4 \%$ of the diet (10 and $20 \%$ of protein).

Quigley (2002) and Scott et al., (1999), however, reported conflicting results when calves fed a diet containing $10 \%$ SDWE (22 to $25 \%$ of the protein) had significantly reduced growth compared with calves fed an all milk protein replacer. However, it should be noted, that in the above studies, calves were not offered calf starter until d 29 of the study, while in the current study and that by Hill et al. (2001) calves were offered a commercial calf starter by the end of the first week of the study.

In the current research, experiments 1,2 , and 3 included diets that contained $5 \%$ of the diet $(13.5 \%$ of the protein) from liquid egg. Hill et al. (2001) also studied various inclusion levels of egg protein in the form of SDWE (3.7, 7.4, and $11.1 \%$ of the diet or 10,20 , and $30 \%$ of the protein). These researchers concluded that at levels less than $11.1 \%$ of the diet (30\% of the protein) that SDWE was a suitable alternative protein source for calves. Previous studies by Quigley (2002), and Scott et al. (1999) evaluated growth and performance measures of calves fed diets containing $10 \%$ or greater of the formula (22\% or greater of the protein) from SDWE. These researchers both summarized that at levels equal to or greater than $10 \%$ of the diet (22\% or greater of the protein) that calf performance was adversely affected. Results reported by all of these researchers and the current study indicate that the upper limit of egg may be $10 \%$ of a milk replacer diet (27\% of the protein) fed at $454 \mathrm{~g} / \mathrm{d}$.

Studies utilizing egg protein as an alternative protein have not reached firm conclusions as to why calves fed diets containing high inclusion levels of egg protein exhibited reduced growth in comparison to calves fed low levels of egg protein in the diet. One suggested explanation is that eggs contain $0.05 \%$ avidin (Lawrence and White, 1989; Pastoor et al., 1991), which combines with biotin to make this essential vitamin unavailable to the calf and thus result in a biotin deficiency. Quigley (2002) evaluated this characteristic of 
egg by adding biotin to calf milk replacer containing SDWE. Results indicated that the addition of biotin to a calf milk replacer containing SDWE did not improve the growth of calves when compared to calves fed the same milk replacer without the additional biotin. Unavailability of biotin may not be the primary reason that high inclusion levels of liquid egg or SDWE resulted in decreased calf performance.

Another potential explanation for decreased calf growth, when liquid eggs or SDWE are utilized in calf milk replacers, is that a number of proteins present in egg white are proteinase inhibitors. The most abundant proteinase inhibitor in egg white is ovomucoid, which accounts for approximately $10 \%$ of the egg white (Kato and Matsuda, 1997). Other inhibitors present at lower levels in egg white include ovoinhibitor, cystatin, and ovostatin. Ovomucoid and ovoinhibitor are both trypsin and chemotrypsin inhibitors. The inhibition of trypsin has been shown to cause growth inhibition as well as pancreatic hypertrophy and hyperplasia (Kato and Matsuda, 1997). However, Kato and Matsuda (1997) have shown that the use of severe heat treatment in neutral or alkaline solutions $\left(100^{\circ} \mathrm{C}\right.$ for $60 \mathrm{~min}$ at $\mathrm{pH}$ 7 or 9) will denature the inhibitory action of chicken ovomucoid. Thus, processing sources of egg protein to denature proteinase inhibitors may be necessary for the inclusion of liquid egg or SDWE at high inclusion levels in calf milk replacers.

A third reason for decreased growth in calves fed high inclusion levels of liquid egg or SDWE may be the simple fact that calves require a minimum amount of milk proteins in their diet. The National Research Council (2001) guidelines for calves fed only milk replacer indicate that $45-\mathrm{kg}$ calves fed $0.46 \mathrm{~kg} / \mathrm{d}$ and growing at $200 \mathrm{~g} / \mathrm{d}$ require approximately $17.6 \%$ of their diet as CP. When a conventional diet consisting of $20 \%$ crude protein is fed containing inclusion levels of alternative proteins greater than 2.4 units of protein, and replacing a portion of the minimum required protein, detrimental effects to the growth of young calves may result.

Evaluations of the current and previous studies assessing liquid egg and SDWE in calf milk replacers indicate that there may be an upper limit on the level of egg protein that can be included in calf diets (Scott et al., 1999; Kellogg et al., 2000; Hill et al., 2001; Quigley, 2002). Including levels of liquid egg or SDWE higher than $10 \%$ of the diet (27\% of the protein) may increase the chances of detrimental effects on calf growth. Or, conversely, greater than $73 \%$ of the protein in milk replacer should come from milk sources to prevent detrimental growth effects.

Numerous research studies have evaluated the use of alternative proteins such as soy, wheat, and plasma proteins in calf milk replacers (Huber and Campos,
1982; Dawson et al., 1988; Terui et al., 1996; Quigley and Bernard, 1996; Quigley et al., 2000). In theses studies, the inclusion level of each alternative protein used replaced 0 to $75 \%$ of the milk protein, in the calf milk replacer diet.

Specific alternative proteins may have upper limits on the percentage of milk protein that they can replace. Animal plasma has been evaluated at levels replacing up to $43 \%$ of the protein in milk replacer (Quigley et al., 2000) and showed no detrimental results on calf performance. Conversely, Huber and Campos (1982) reported that feeding soy protein concentrate at inclusion levels of $33 \%$ of the protein reduced weight gains by $14 \%$. Further, when hydrolysate of fish was included at the same level as soy protein concentrate, weight gains were further reduced by $13 \%$ (27\% lower weight gains than calves fed an all milk protein diet).

In all of the studies reported previously (Scott et al., 1999; Kellogg et al., 2000; Hill et al., 2001; Quigley, 2002) the source of egg used to manufacture the trial diets was SDWE. Hill et al. (2001) evaluated the effects of feeding two sources of SDWE at the same inclusion rate ( $7.4 \%$ of the formula, or $20 \%$ of the protein). These researchers reported that the source of egg caused significant differences in growth of the calves.

For the diets used in the current study, the source of egg included in the experimental diets was breaker eggs in liquid form which was then co-dried with other liquid protein and fat ingredients and pasteurized prior to spray-drying (Figure 1). This is in contrast to previous research studies evaluating egg protein in calf milk replacers who included egg proteins as SDWE (Scott et al., 1999; Kellogg et al., 2000; Hill et al., 2001; Quigley, 2002). Additionally, these researchers also manufactured the entire diet from dry ingredients, while at Merrick's Animal Nutrition, Inc., all diets were mixed in liquid form prior to spray-drying. These differences in manufacturing may allow for greater control of the egg proteins during manufacturing. This may also explain some of the differences in calf performance when egg proteins are included at rates of $10 \%$ of the formula (or $27 \%$ of the protein).

\section{CONCLUSIONS}

The addition of liquid egg to calf milk replacers at levels of $10 \%$ or less of the diet $(27 \%$ or less of the protein) when calves have access to starter feeds did not significantly affect growth of young calves fed a conventional milk replacer program of $454 \mathrm{~g} / \mathrm{d}$. Feeding high inclusions rates of liquid egg (15\% of the formula or $40.5 \%$ of the protein), however, reduced growth and performance of calves. Liquid egg is a suitable alterna- 
tive protein in calf milk replacers when fed at low inclusion rates and moderate feeding rates.

\section{REFERENCES}

Dawson, D. P., J. L. Morrill, P. G. Reddy, H. C. Minocha, and H. A. Ramsey. 1988. Soy protein concentrate and heated soy flours as protein sources in milk replacer for preruminant calves. J. Dairy Sci. 71:1301-1309.

Hill, T. M., J. M. Aldrich, A. J. Proeschel, and R. L. Schlotterbeck. 2001. Feeding neonatal calves milk replacers containing egg proteins. J. Dairy Sci. 84(Suppl. 1): 265. (Abstr.)

Huber, J. T., and O. F. Campos. 1982. Enzymatic hydrolysate of fish, spray-dried fish solubles, and soybean protein concentrate in milk replacer for calves. J. Dairy Sci. 65:2351-2356.

Kato, Y., and T. Matsuda. 1997. Glycation of proteinous inhibitors: Loss in trypsin inhibitory activity by the blocking of arginine and lysine residues at their reactive sites. J. Agric. Food Chem. 45:3826-3831.

Kellogg, D. W., Z. B. Johnson, K. E. Lesmeister, and K. S. Anshutz. 2000. Growth of calves fed milk replacer containing dried egg product. AAES Res. Ser. 478:149-153.

Lawrence, B., and H. B. White. 1989. Avidin traps biotin diffusing out of chicken egg yolk. Comp. Biochem. Physiol. 93B:543-547.
National Research Council. 2001. Pages 214-233 in Nutrient Requirements of Dairy Cattle. 7th rev. ed. Natl. Acad. Sci., Washington, DC.

Pastoor, F. J., H. Van Herck, A. Th. Van't Klooster, and A. C. Beynen. 1991. Biotin deficiency in cats as induced by feeding a purified diet containing egg white. J. Nutr. 121:S73-S74.

Quigley, J. D. III. 2002. Effects of spray-dried whole egg and biotin in calf milk replacer. J. Dairy Sci. 85:198-203.

Quigley, J. D. III, and J. K. Bernard. 1996. Milk replacers with or without animal plasma for dairy calves. J. Dairy Sci. 79:18811884.

Quigley, J. D. III, C. A. Jaynes, M. L. Miller, E. Schanus, H. ChesterJones, G. D. Marx, and D. M. Allen. 2000. Effects of hydrolyzed spray dried red blood cells in milk replacer on calf intake, body weight gain, and efficiency. J. Dairy Sci. 83:788-794.

Scott, T. A., T. Tomkins, D. Vermeire, and N. K. Keith. 1999. Evaluation of alternative protein milk replacers on growth and health of Holstein heifer calves. J. Dairy Sci. 82(Suppl. 1):46. (Abstr.)

Systat 8.0 Statistics. 1998. SPSS Inc. Chicago, IL.

Terui, H., J. L. Morrill, and J. J. Higgens. 1996. Evaluation of wheat gluten in milk replacer and calf starter. J. Dairy Sci. 79:12611266.

USDA. 2003. Subject: Dairy Commodity Average Prices. http:// www.ams.usda.gov/dairy/mncs/average.htm. Accessed January, 2003. 